\title{
Platonov Revisited. Past and Present Views on the Land of the Philosophers
}

\author{
Ben W. Dhooge \& Thomas Langerak
}

The disclosure of Platonov's long forbidden and inaccessible oeuvre and the subsequent startup and maturation of its scholarly study, by scholars worldwide, have been showing an irregular, bumpy and fragmentary course since the writer's death in 1951. Early Platonov studies, from the mid-1960s onwards, centered around certain works, like 'Такыр' (Takyr), 'Мусорный ветер' (Rubbish wind), 'Фро' (Fro), 'В прекрасном и яростном мире' (The fierce and beautiful world), 'Река Потудань' (The Potudan River) or 'Одухотворенные люди' (Inspired people), all of which were considered acceptable by the Soviet authorities and Soviet printing houses and journals ${ }^{1}$ (or were altered even, to a greater or lesser degree, by them in order to make them acceptable ${ }^{2}$. The actual disclosure of Platonov's most wellknown works took place in the second half of the twentieth century, and initially even at different paces in Russia and abroad. While in Europe and the United States, Platonov's Чевенгур (Chevengur) and 'Котлован' (The foundation pit) found their way to the public as early as in the 1960s and the $1970 \mathrm{~s}^{3}$ and led to a series of scholarly publications on Platonov's oeuvre, in Russia these masterpieces were published only in the perestroika era ${ }^{4}$. Of course, Platonov's 'major' works had already been known before in certain circles (like people active in the samizdat), but often in an incomplete form. The publication of the novel and the novella - with the author's postscript! - and the subsequent edition of other unknown and forbidden works, like 'Антисексус' (Antisexus) and Счастливая Москва (Нарру Moscow), in enormous print runs in Russia gave a strong impulse to the existing scholarly study of Platonov's work, both in Russia and abroad.

Soon letters, notes and unknown literary works of the writer-engineer, reactions to the campaign against 'Впрок' (For future profit), reports of the writer's appearances at the Writers' Union and much more were brought into the open. Archives of the Stalin era and other sources were opened up for the public, allowing scholars to start revealing previously unknown facts about Platonov's life and oeuvre and restoring the original versions of his literary works that had been censored and altered in the past by editors and publishers. Several collections of scholarly writings came out, like Андрей Платонов. Мир творчества (Andrej Platonov. The universe of his oeuvre - Платонов 1994a), Андрей Платонов. Воспоминания современников. Материальк к биографии (Andrej Platonov. Memories of his contemporaries. Materials for the writer's biography - Платонов 19946), the first two volumes of the series "Страны философов" Андрея Платонова (Andrej Platonov's "Land of the philosophers" - Корниенко 1993; Корниенко 1995). Fruitful contacts between Russian and non-Russian scholars, who logically also experienced an increased interest in Platonov's newly discovered literary oeuvre, were established. The political changes and the boom in scholarship and publications led to a certain

\footnotetext{
${ }^{1} \mathrm{Cf}$., in this respect, Скобелев et al. 1970.

${ }^{2}$ See, e.g., Платонов 2004a: 7-8.

3 'The foundation pit' was published for the first time in 1969 in London (in Russian, in the journal Cmydeнm. Журнал авангарда советской литературы (Student. A journal for the avant-garde of Soviet literature), vol. 13-14), and in 1973 in Ann Arbor, Michigan (in Russian and English). Chevengur came out in Paris in 1972 (in Russian, but without the first part 'Происхождение мастера' (The origin of a master); also, in that same year, a French translation appeared), and in 1978 in Ann Arbor, Michigan (in English).

${ }^{4}$ In Soviet Russia Čevengur was published for the first time in 1988 in the journal Дружба народов (Реорles' friendship), and also as a separate publication (Издательство Художественная литература, Publishing house Belles-lettres). 'The foundation pit' first appeared in Soviet Russia in 1987, in the journal Hовый мир (New world).
} 
deideologization or depoliticization. Scholars started to write about Platonov's oeuvre outside of (the previously almost obligatory) ideological presumptions. Where previously Soviet scholars had chiefly considered Platonov to be a genuine proletarian, pro-communist writer, while Western scholars saw him as a classic example of an anti-Soviet writer, now other ideas about Platonov's ideological positions started to gain ground, too. All this contributed to the successful development of Platonov studies and transformed them into the fully fledged scholarship it is today, with scholars working on his life and oeuvre not only in Russia, Europe, the Anglo-American world, but also in other countries, like Japan and Korea.

On looking back at the last ten years, the results of that scholarship are obvious.

During the past decade there have been several seminars and conferences on Platonov. Besides the many international seminars at Voronezh State University (2001, 2004 and 2011) and the Pushkin House in St. Petersburg (IRLI RAN) (2000, 2001, 2002, 2003, 2004, 2005 and 2006), there have been three conferences at the Gorky Institute of World Literature in Moscow (IMLI RAN), devoted to the writer's literary oeuvre from the second half of the 1930s to the 1940s (2001), the novel Chevengur (2004) and Platonov's dramatic art and plays (2009). In 2000 the British Neo-Formalist Circle hosted the conference 'A Hundred Years of Andrei Platonov' at Oxford University, Mansfield College, which was organized by Angela Livingstone, Joe Andrew and Robert Reid. In 2002 Ayleen Teskey organized a conference on Platonov in Londonderry (University of Ulster, Magee College). In 2008 there was a Platonov conference entitled 'Andrej Platonov - ein Autor zwischen allen Stühlen?' in Munich, organized by Renata Döring Smirnov, Hans Günther and Aage Hansen-Löve. In February 2011 Columbia University, New York, and the Harriman Institute hosted the conference 'Andrei Platonov: Style, Context, Meaning', organized by Katharine Holt and Boris Gasparov. In May 2011 at Ghent University, Ghent, the conference 'Platonov Revisited. Past and Present Views on the Land of the Philosophers' and the translation seminar 'Amidst Smoke and Different Questions', both organized by Ben Dhooge and Thomas Langerak, took place.

In the last decade at least 19 monographs, partly or entirely devoted to Platonov, were published. ${ }^{5}$ Furthermore, two companions to 'The foundation pit' appeared, one in English, written by Thomas Seifrid (2009), and one in Russian, by Natal'ja Dužina (2010). In 2011 Aleksej Varlamov's biography of Platonov, based on a great amount of biographic and philological studies, came out in the well-known series 'Жизнь замечательных людей' (Lives of remarkable people - Варламов 2011). Several edited volumes on Platonov's life and oeuvre have been published. Think, for example, of the Petersburg series Творчество Платонова (Platonov's oeuvre - Колесникова 2004; Колесникова 2008) and the Moscow series “Страна Философов" Андрея Платонова (Andrej Platonov's "Land of the philosophers" - Корниенко 2000; Корниенко 2003; Корниенко 2005; Корниенко 2011), or the separate editions by Voronezh State University (Мущенко et al. 2001; Никонова \& Алейников 2004). Other important edited volumes are the special issues of Essays in Poetics (Livingstone 2001a, 2001b), Wiener Slawistischer Almanach (Günther \& Hansen-Löve 2009) and Ulbandus (Holt 2012). Equally significant is the scholarly edition of Platonov's oeuvre, which started to come out in 2004 (Платонов 2004a, 2004б). And, of course, Platonov scholars around the world continue to publish their findings on Platonov (the man, the writer, the thinker, the engineer) in a great number of scholarly journals, on the most diverse topics. ${ }^{6}$

Nonetheless, it seems that all these accomplishments are only another step of many to come in the evolution of Platonov scholarship. Firstly, much research work lies ahead of us

\footnotetext{
${ }^{5}$ Cf. Костов 2000; Hodel 2001; Яблоков 2001; Толстая 2002; Корниенко 2003; Михеев 2003; Livers 2004; Вьюгин 2004; Баршт 2005; Bullock 2005; Chlupáčová \& Zadražilová 2005; Красовская 2005; Малыгина 2005; Спиридонова 2005; Юрьева 2005; Радбиль 2006; Злыднева 2006; Gyimesi 2010; Гюнтер 2011.

${ }^{6}$ On the main tendencies in Platonov scholarship during the last 10-11 years, cf. Богомолова \& Дооге 2012.
} 
still, despite the steady, firm progress. For example, Platonov's technological 'oeuvre' remains largely unexplored. ${ }^{7}$ Besides, the study of the writer's complex literary oeuvre continues to raise many new questions, both in the field of research topics and research methods. Secondly, even today Platonov's heritage has not been fully disclosed yet. A great part of it had long been kept in the writer's personal archive - preserved for future generations by Platonov's widow Marija Aleksandrovna and, later, his daughter Marija Andreevna - and only a part of it found its way to publication (sometimes in a corrupted form, however). At first, separate articles (e.g. 'Электрическое орошение почвы' - Electric irrigation of the soil, Платонов 2004б: 300-305) and novellas (е.g. 'Антисексус' Antisexus, Платонов 1981), parts of Platonov's notebooks (Платонов 1972; 1990), some letters (Платонов 1975) and some photographs (Платонов 1994б) found their way to the public domain. And just recently, in the past decade, Natal'ja Kornienko has managed to make Platonov's notebooks and a large proportion of his plays and film scripts accessible to readers and researchers (cf. Платонов 2000; Платонов 2006). In 2006, the Gorky Institute of World Literature at the Russian Academy of Sciences (IMLI RAN) acquired Platonov's 'home archive' or 'family archive'. Since then the Platonov research group at the Institute of World Literature under the direction of Natal'ja Kornienko has started to publish previously unknown materials and to restore and republish other, already known texts and materials, that in the past had been corrupted by editors and censors for various reasons. See in this respect the first volume (2009) of a new series, Архив А. П. Платонова (A. P. Platonov's archive), which brought into the open a vast amount of new and restored materials, including manuscripts, typescripts, letters, photographs and the like. The rest of Platonov's personal archive will follow in the near future. Despite the fact that up to now only a fragment of Platonov's 'home archive' has been made known it is already obvious that the acquisition of Platonov's personal archive by the Russian Academy of Sciences is a new landmark in Platonov scholarship. Not only will it enable Platonov scholars to get a better, more complete view on the writer's life, his oeuvre, the background and the coming into being of his works, but most certainly it will also force scholars to re-evaluate and reconsider the scholarly work written in the past 30-40 years.

Re-evaluation and reconsideration are key words in Platonov studies, and not only because of the 'physical hindrances' on the road to Platonov's hidden "Land of the Philosophers" - which caused, for example, the writer's plays and film scripts to remain scarcely studied until recently - or because of the very nature of the writer's literary oeuvre as a subject of research - in particular, its complexity and ambivalence. Politicized readings of the writer's oeuvre - procommunist or anticommunist, depending on the ideological context the scholar found himself in, - dominated Platonov studies until late in the perestroika era. Later, other aspects of Platonov's exceptional legacy - e.g. its philosophical and mythopoetic nature - started to prevail over ideology, sometimes pushing into the background the undeniable - and still crucial for an adequate understanding of the writer's texts - (more and more historically distant) sociopolitical context. Recently a renewed interest in the historical context, but without the ideological bias, started to gain ground, again. At the same time, with the continuously growing understanding of the most diverse aspects of Platonov's literary oeuvre, ranging from textology over 'sheer' poetics to philosophical themes, and its forthcoming complete disclosure, the researchers' attention started broadening to its direct context: literary, cultural and political life in Soviet Russia between 1918 and 1951. Obviously, the link with literary and cultural life beyond the borders of Soviet Russia also received more and more attention. Platonov's place in the canon of $20^{\text {th }}$ -

\footnotetext{
${ }^{7}$ An interesting work on the topic is Ch. Harwood's Ph.D. dissertation Human Soul of an Engineer: Andrei Platonov's Struggle with Science and Technology. New York, 2000.
} 
century literature in general and Russian literature, in particular, is, therefore, one of the new key topics in current research (cf., for example, the 2008 conference in Munich). Not infrequently, typological issues (i.e. possible convergences with representatives from different periods, regions or even forms of art) are foremost in this research. ${ }^{8}$ This focus on Platonov's 're-contextualization' is part of a larger picture. New and/or revised concepts and scholarly paradigms in literary theory that may be of interest in Platonov scholarship (e.g. the notion of 'Modernism') also came under the spotlight. It is worth noting the opposite, too: the accumulating insights into the peculiarities of Platonov's literary oeuvre possibly allow scholars to challenge existing concepts and paradigms in literary theory (e.g. Platonov's peculiar portraits) or even to unveil previously unnoticed aspects of literary creation (e.g. certain aspects of the author's linguistic creation).

Today, approximately a quarter of a century after the publication of Chevengur and 'The foundation pit' in a more or less complete form in the Soviet Union, forty years after the appearance of the first scholarly studies on Platonov ${ }^{9}$, and on the eve of new revelations on the writer's life and oeuvre, it is a good moment to stop and reflect, and to have a look at the Platonov studies, past and present. In 2011 the Department of Slavonic and East European Studies at Ghent University organized, with the financial support of the Faculty of Arts and Philosophy and the Research Foundation - Flanders (FWO-Vlaanderen), a conference (May $26-28,2011)$ on the changes in the reception of Platonov and his works over the last twenty to thirty years. A selection of the papers presented at the conference has been bundled in this special issue of Russian Literature. They primarily deal with the changes in the scholarly study of Platonov and his works. (Another selection of articles, dealing with the readers' reception of Platonov's oeuvre, has been collected together into a separate edited volume (Возвращаясь к Платонову, 2013 - Platonov revisited).

Re-evaluation, reconsideration, change and evolution are keywords in Hans Günther's article 'Временное и вневременное у Платонова: предварительные соображения' (The temporary and timeless of Platonov: preliminary thoughts), which provides an overview of the gradual, but fragmentary and erratic disclosure of Platonov's oeuvre and the evolution of Platonov scholarship from within - from the point of view of one of the first leading Platonov scholars. Specific attention is paid to the fact that with the Soviet epoch becoming more and more distant, philosophic, mythopoetic and anthropologic themes have become more prominent, overshadowing rather the primary sociopolitical and historical context as an object of research. This did not prevent Platonov scholarship, however, from striving to broaden its research to other 'temporal aspects', like the relationship to Russian and world culture. To the present-day reader the historical distance, however, argues Günther, presents an extra challenge.

Despite the historical distance, the primary context can still be important, if not essential. Natal'ja Dužina's article “'Котлован' и ‘философия общего дела': прошлый и нынешний взгляд на проблему 'воскрешения мертвых' у А. Платонова и Н. Федорова' ('The foundation pit' and 'the philosophy of the common cause': past and present views on the problem of the 'resurrection of the dead' by A. Platonov and N. Fëdorov) illustrates the advantages of studying Platonov's direct context for an adequate understanding of difficult aspects of and passages in the writer's oeuvre. Focusing on utilsyr' $\ddot{e}$ (salvage) and the issue of resurrection in 'The foundation pit', the author shows that the historical context - the 1930 Soviet campaign to collect salvage and Stalin's industrialization program, which started in

\footnotetext{
${ }^{8}$ Cf., for example, Gyimesi 2010; Leichter-Flack 2007; Sokolyansky 2002; Кеба 2004; Кеба 2008; Полтавцева 2004; Ходел 2008.

${ }^{9}$ It is important to note that some really good analyses, despite the obvious ideologically inspired vitriol, can be found in some critical pieces that appeared during Platonov's life. Cf., for example, Майзель 1930; Гурвич 1937.
} 
1928 and implied not only a need for salvage, but also for extra working hands, the living utilsyr' $\ddot{e}$ or the many peasants looking for a job (the otchodniki or seasonal workers) - is crucial for understanding Platonov. Moreover, the historical context, as Dužina argues, may even question and correct some already established views on the writer and his oeuvre. Sometimes it is not the historical context but the personal context that may be essential for reading Platonov. In 'Значение публикации документов по делу сына А. Платонова для платоноведения (на примере рассказа 'По небу полуночи')' (The publication of the documents on the case of Platonov's son and its significance for Platonov scholarship (On the example of 'In the midnight sky') Ljudmila Surovova elucidates the influence of the arrest of Platonov's son Platon in 1938 on the writer's literary oeuvre, more specifically on his antifascist short story 'По небу полуночи' (In the midnight sky), which was written a year after the arrest. The author also alludes to the historical events and the events in Platonov's personal and literary life which all played a role in the creation of the short story.

Katharine Holt emphasizes the significance of the cultural context for Platonov studies in her paper 'Collective authorship and Platonov's Socialist Realism'. The author suggests reading the short stories 'Такыр' (Takyr) and 'Одухотворенные люди' (Inspired people) in their original context, i.e. as a part of the collectively authored volumes АйдингГюнлер: Альманах к десятилетию Туркменистана, 1924-1934 (Radiant days: The almanac for the $10^{\text {th }}$ anniversary of Turkmenistan, 1924-1934, 1934) and Сталинское племя (Stalin's tribe, 1943). This approach, i.e. considering the original, collective and typically Socialist Realist context the short stories appeared in, sheds new light on Platonov's short stories, both revealing the similarities between Platonov's works and the collective literary works and highlighting the uniqueness of his voice within the collective and against a background of Socialist Realism. The historical-cultural context - and its importance for an adequate understanding of certain peculiarities in Platonov's oeuvre - also plays a key role in the articles by Evgeny Pavlov, Kornelija Ičin, and Il'ja Kukuj. In his paper ' Nenužnoe vremja': Time in Platonov's 'Socialist Realist' stories' Evgeny Pavlov focuses on Platonov's conception of time in his 'Socialist Realist' stories 'Река Потудань' (The Potudan River) and 'Среди животных и растений' (Among animals and plants) in relation to the Stalinist conception of time and history. Both conceptions seem to share the same characteristics: a constant tendency towards a close interrelationship between time and space, circularity, and "belatedness" - i.e. the idea that the future has passed by us already. In his 'Socialist Realist' stories, however, Platonov lays bare the deceptiveness of the Stalinist conception of world history - the idea of having mastered time, of having reached the utopia the social classes long struggled for - and stresses the hope of the individual to reach "the end of time" - the realization of the end of death and suffering, the ultimate transformation of society. In 'Инженер в производственном процессе: 'Высокое напряжение' А. Платонова' (An engineer in the production process: A. Platonov's 'High voltage') Kornelija Ičin connects the image of the engineer and the theme of engineering in Platonov's play 'Высокое напряжение' (High voltage, 1931) not only with the changes in the writer's views on poetics after the vitriolic critique on his "poor peasant's" chronicle 'Впрок' (For future profit), but also against the Russian and European cultural backgrounds of the late 1920s and early 1930s, when engineering, production and mechanical progress were a key topic, especially in cinema (cf. L. Kulešov's Проект инженера Прайта (Engineer Prite's project), Ja. Protazanov's Аэлита (Aèlita) or F. Lang's Metropolis). Il'ja Kukuj juxtaposes the oeuvres of the writer Andrej Platonov and the film director Aleksandr Medvedkin and their respective reception in an article entitled 'Метаморфозы советского художника: А. Платонов и А. Медведкин' (Metamorphoses of a Soviet artist: A. Platonov and A. Medvedkin). The author reflects on the discrepancies between both artists' original pro-Soviet intentions and the often opposite, 
i.e. negative, interpretation of their unusual, alienating, maximally sincere and correct approach to the Soviet ideologemes by their contemporaries and later interpretation 'layers'.

The different interpretation 'layers' figure prominently in the paper by Natal'ja Kornienko, 'Военные рассказы А. Платонова: историческая динамика восприятия' (А. Platonov's wartime stories: the historical dynamics of reception), where she discusses the differences in reception of Platonov's wartime stories. In this paper, which boasts a vast amount of new archival materials and socio-historical background information, the author discerns and describes four periods in the history of the reception and study of these short stories - during his life (1942-1946), the first decade after the author's death, the Thaw period, and the present-day period, which started in the second half of the 1980s. As Kornienko points out, the most detailed and correct analyses were written by Platonov's contemporaries, who noticed that his war prose is a logical continuation not only of the writer's main ideas and views, but also of the rich Tolstoyan tradition of prose on war and peace in Russia. Later, interest in Platonov's war prose gradually disappeared, and nowadays it has become peripheral compared to the rest of the writer's oeuvre. Il'ja Kukuj sheds light on a different aspect of reception that did not get much attention until now - the reception of Platonov's oeuvre in the samizdat community. In issue 17 of the Leningrad samizdat journal 37, Kukuj found an article on Platonov by a certain S. Vedruchin (a pseudonym), written in 1979, but which went unnoticed or has been forgotten by scholars until today. In the 1970s other scholarly articles on Platonov's oeuvre by now leading scholars - Natal'ja Kornienko, Nina Malygina, Natal'ja Poltavceva, Svetlana Semënova et al. - found their way to the public too, but this article, not being hindered by any ideological restrictions or issues of censorship, was far ahead of its time. For those reasons this article - 'Заметки о прозе А. Платонова' (Notes on A. Platonov's prose), - which analyzes Platonov's oeuvre from a philosophical perspective, is reprinted in this issue of Russian Literature.

Another article deals with a different aspect of reception - the reception of Platonov's oeuvre by other artists. Alexandra Smith's article 'Andrej Platonov through a lens of postmodern melancholy: Lev Dodin's Chevengur (1999)' focuses on the interpretation of Platonov's novel by stage director Lev Dodin and on his attempts, Brodsky-like, to get the audience involved in the debate on topical concepts such as truth, faith, the limitations of language, etc. The author also focuses on the stage director's views on totalitarianism and (communist) utopian thinking with regard to other writings by leading scholars (like A. Jurčak, M. Epstein, B. Groys, etc.) and writers (A. Solženicyn, A. Blok, N. Berdjaev, L. Losev, A. Kollontaj, etc.)

Aspects of reconsideration or re-evaluation in poetic analysis are prominent in the papers by Marija Bogomolova and Irina Šatova. In 'Портрет в прозе Андрея Платонова: итоги изучения и нерешенные проблемы' (Portraits in A. Platonov's prose: results and unresolved problems) Marija Bogomolova shows that the categories and concepts normally used in traditional studies of literary portraits do not hold when analyzing Platonov's portraits. The author illustrates some of the main peculiarities of Platonov's portraits, and links them with the writer's exceptional poetics and his particular conceptualization of the world. The author also tries to find an answer to questions that arise when looking at Platonov's portraits from a traditional point of view, for example: do Platonov's portraits, in all their unusualness, serve as a means of characterization and do they allow us to construct a typological classification of Platonov's characters? In her paper ‘Звукопись и анаграмматизм в художественном мире Андрея Платонова: метаморфозы рецепции' (Zvukopis' and anagrams in Andrej Platonov's artistic world: reception metamorphoses), Irina Šatova examines Platonov's oeuvre in the context of experiments with sound, anagrams and cryptographic writing in literature, so typical of poetry in the late $19^{\text {th }}$ and early $20^{\text {th }}$ centuries. The author argues that these sound experiments may have influenced Platonov: not only was 
the writer interested in these experiments, he himself, as states Šatova, also experimented with sound (sound associations, repetition of certain sounds, sound images, use of anagrams and paronyms, etc.) and with cryptographic writing. Šatova illustrates these experiments with sounds and their functions in the text on the basis of several poems, the novella 'Сокровенный человек' (The innermost man) and the montage story 'Антисексус' (Antisexus).

Thomas Seifrid broadens the practice of re-evaluation to include Platonov's attitude towards reality, towards the State. In 'Platonov and dissidence', Seifrid focuses on Platonov's attitude towards the State's ideology, the State's discourse. Platonov's attitude can be characterized as "dissent" - and it is exactly this that connects him to other 'dissident' writers in Russian culture, like P. Čaadaev, M. Saltykov-Ščedrin and A. Radiščev. At the same time, however, Platonov's "dissent" is very different from those other forms as, essentially, it has become a natural part of the State's ideology. Consequently, Platonov's "dissent" cannot be seen as a mere artistic expression of non-acceptance of the Soviet system but, more objectively, as a conscious entry into the field of the State's discourse, while still objecting to it, and refuting it.

A last cluster of articles deals with the possible relationship between Platonov and Modernism / the Avant-garde. In 'Platonov and theories of Modernism', Philip Bullock focuses on two interrelated problems: how can Platonov's peculiar writing style be defined; and what place does Platonov's literary oeuvre occupy in the fields of Russian literature and world literature? After underlining differences in the perception of Platonov's style between the West (where he was widely considered to be a Modernist or Avant-garde writer) and in Russia (where he was perceived mainly in the light of Realism), the author concludes that, despite the obvious formal similarities between Platonov's oeuvre and Modernist / Avantgarde literature, the actual link with Modernism / Avant-garde is not only complex, but also problematic. Furthermore, as Bullock puts it, it may be more interesting to focus on Platonov as a possible follower of 'Tolstoyan realism', a literary 'school' that the writer is usually not associated with in scholarly writings, despite the influence it had on a whole generation of Russian 'Modernists' in the 1920s. This tendency - i.e. to disapprove everything 'Realist' was started by Joseph Brodsky who considered Platonov's oeuvre to be 'Modernist', and anything but 'Realist' - an interpretation which is actually based on a predominantly appreciative understanding of the phenomena and concepts in question. The link between Platonov and Modernism / Avant-garde is also the main topic in Dennis Ioffe's paper: 'Andrej Platonov and the pragmatics of the radical Modernism'. Approaching Platonov's oeuvre from the point of view of semiotics, the author focuses on the different 'life-building' aspects of Platonov's 'creative pragmatics', as expressed in his oeuvre and his egodocuments - experimental poetics, surrealist situations, the aspiration to overcome death and history, a positivist utopianism, the importance of 'life-building', the attention to technology, machines, electricity, etc. - with regard to the creative aspects of the Russian and European historic Avant-garde.

\section{Literature cited}

Bullock, Philip R.

2005 The Feminine in the Prose of Andrey Platonov. London.

Chlupáčová, Kamila \& Miluše Zadražilová

2005 Texty a kontexty Andreje Platonova. Praha.

Günther, Hans \& Aage A. Hansen-Löve (eds.)

2009 Diesseits und jenseits der Utopien. Andrej Platonov - ein Autor zwischen allen Stühlen. In: Wiener Slawistischer Almanach, Band 63. 
Gyimesi, Zsuzsanna

2010 Andrej Platonov prózája és Pavel Filonov festészete. Tipológiai párhuzamok az 1910-20-as évek orosz-szovjet müvészetében. Budapest.

Hodel, Robert

2001 Erlebte Rede bei Platonov: von "V zvezdnoj pustyne" bis "Cevengur".

Frankfurt am Main.

Holt, Katharine

2012 Andrei Platonov: Style, Context, Meaning. In: Ulbandus 14 (2011-2012).

Leichter-Flack, Frédérique

2007 'Le Kafkaïen, outil du politique au vingtième siècle? Un détour par Platonov'.

In: Philippe Zard (ed.), Sillage de Kafka. Paris, 365-380.

Livers, Keith

2004 Constructing the Stalinist Body: Fictional Representations of Corporeality in the Stalinist 1930s. Lanham.

Livingstone, Angela (ed.)

2001a A hundred years of Andrei Platonov, Vol. 1. In: Essays in Poetics, vol. 26:

Keele.

2001b 'A hundred years of Andrei Platonov, Vol. 2. In: Essays in Poetics, vol. 26:

Keele.

Seifrid, Thomas

2009 A Companion to Andrei Platonov's The Foundation Pit. Boston.

Sokolyansky, Mark

2002 'Andrei Platonov and Franz Kafka: A typological study', Russian literature, 51/1, 73-90.

Баршт, К. А.

2005 Поэтика прозы Андрея Платонова. Санкт-Петербург.

Богомолова, М. В. \& Б. В. Дооге

2012 'Андрей Платонов в пространстве современной филологии (2000-2011)', Вестник московского университета, Серия 9: Филология, 1 (2012): 165183.

Варламов, Алексей

2011 Андрей Платонов. Москва.

Вьюгин, В. Ю.

2004 Андрей Платонов: поэтика загадки (Очерк становления и эволюичи стиля). Санкт-Петербург.

Гурвич, А. С.

1937 'Андрей Платонов’. Красная Новь, 10 (1937), 195-233.

Гюнтер, Ханс

2011 По обе стороны от утопии: контексты творчества А. Платонова. Москва.

Дужина, Н. И.

2010 Путеводитель по повести А. П. Платонова “Котлован”. Москва.

Злыднева, Н. В.

2006 Мотивика прозы Андрея Платонова. Москва.

Кеба, А. В.

2004 'Роман Андрея Платонова “Чевенгур” и поэтика модернистской прозы' In: Т. А. Никонова,. \& О. Ю. Алейников (eds.), Роман А. Платонова "Чевенгур": авторская позиция и контексты восприятия. Воронеж, 206-222. 
2008 'Игра в поэтике Андрея Платонова и Джеймса Джойса (Типологический аспект)'. In: Е. И. Колесникова (ed.), Творчество Андрея Платонова, Кн. 4.

Санкт-Петербург, 22-38.

Колесникова, Е. И. (ed.)

2004 Творчество Андрея Платонова. Исследования и материаль, Кн. 3.

Санкт-Петербург.

2008 Творчество Андрея Платонова: Исследования и материаль, Кн. 4.

Санкт-Петербург.

Корниенко, Н. В.

2003 “Сказано русским языком...” Андрей Платонов и Михаил Шолохов:

встречи в русской литературе. Москва.

Корниенко, Н. В. (ed.)

1993 “Страна философов” Андрея Платонова: проблемы творчества, Вып. 1. Москва.

1995 “Страна философов” Андрея Платонова: проблемы творчества, Вып. 2. Москва.

2000 “Страна философов” Андрея Платонова: проблемы творчества, Вып. 4. Москва.

2003 “Страна философов” Андрея Платонова: проблемы творчества, Вып. 5. Москва.

2005 “Страна философов” Андрея Платонова: проблемы творчества, Вып. 6. Москва.

2011 “Страна философов” Андрея Платонова: проблемы творчества, Вып. 7. Москва.

Костов, Хели

2000 Мифопоэтика Андрея Платонова в романе "Счастливая Москва". Helsinki.

Красовская, С. И.

2005 Художественная проза А. П. Платонова: жанры и жанровые процессы. Благовещенск.

Майзель, М.

1930 'Ошибки мастера', Звезда, 4 (1930), 195-202.

Малыгина, Н. М.

2005 Андрей Платонов: поэтика “возвращения”. Москва.

Михеев, М. Ю.

2003 В мир Платонова через его язык. Москва.

Мущенко, Е. Г. et alii (eds.)

2001 Осуществленная возможность: А. Платонов и ХХ век. Воронеж.

Никонова, Т. А. \& О. Ю. Алейников (eds.)

2004 Роман А. Платонова "Чевенгур": авторская позиция и контексть восприятия. Воронеж.

Платонов, А. П.

1972 “Из записных книжек”, Кубань, 2 (1972), 65-70.

1975 “... Живя главной жизнью (А. Платонов в письмах к жене, документах и очерках”, Волга, 9 (1975), 160-178.

1981 'Antiseksus'. Russian Literature, 9/3, 281-295.

1990 Деревянное растение. Из записных книжек. Москва.

1994а Андрей Платонов. Мир творчества. Москва.

1994 Андрей Платонов. Воспоминания современников. Материальк к биографии. Москва. 
2000 Записныле книжки. Материалы к биографии. Москва.

2004а Сочинения, Том 1, Книга 1. Рассказы. Стихотворения. Москва.

20046 Сочинения. Том 1, Книга 2. Статьи. Москва.

2006 Ноев ковчег: пьесы. Москва.

Полтавцева, Н. Г.

2004 'Мотив сиротства как проблема культуры у Платонова и Джойса: Саша Дванов и Стивен Дедалус'. In: Е. И. Колесникова (ed.), Творчество Андрея Платонова, Кн. 3. Санкт-Петербург, 263-280.

Радбиль, Т. Б.

2006 Языковые аномалии в художественном тексте: Андрей Платонов и другие. Москва.

Скобелев, В. П. et alii (eds.)

1970 Творчество А. Платонова. Статьи и сообщения. Воронеж.

Спиридонова, И. А.

2005 “Внутри войны” (поэтика военных рассказов А. Платонова).

Петрозаводск.

Толстая, Е. Д.

2002 Мирпослеконща: Работы о русской литературе ХХ века. Москва.

Ходель, Р.

2008 'Платонов - Кафка - Вальзер: Опыт подготовительного исследования'. In:

Елена Колесникова (ed.), Творчество Андрея Платонова, Кн. 4. Санкт-

Петербург 2008, 48-61.

Юрьева, Л. М.

2005 Русская антиутопия в контексте мировой литературы. Москва.

Яблоков, Е. А.

2001 На берегу неба (роман Андрея Платонова “Чевенгур”). Санкт-Петербург. 